\title{
Evaluation of Cytotoxic Activity of Sargassum vulgare From the Lebanese Coast Against Jurkat Cancer Cell Line
}

\author{
Mona Y. Tannoury ${ }^{\mathrm{a}}$, Josiane M. Elia ${ }^{\mathrm{a}}$, Antoine M. Saab ${ }^{\mathrm{c}}$, Hassane Y. Makhlouf ${ }^{\mathrm{b}}$, Jihad S. Abboud ${ }^{\mathrm{d}}$, Roula J. Daou- \\ Chabo $^{\mathrm{a}}$, Mona Diab-Assaf ${ }^{\mathrm{b}^{*}}$ \\ ${ }^{a}$ Department of Bilogy, Faculty of Science II, Lebanese University, Lebanon. \\ ${ }^{\mathrm{b}}$ Doctoral School of Science and Technology, Lebanese University, Hadath, Lebanon. \\ ${ }^{c}$ Department of Chemistry, Faculty of Science II, Lebanese University, Lebanon. \\ ${ }^{\mathrm{d}}$ Department of Animal Sciences, Faculty of Agriculture and Animal Sciences. Lebanese University, Lebanon.
}

\section{ARTICLE INFO}

Article history:

Received on: 22/01/2016

Revised on: 03/03/2016

Accepted on: 06/04/2016

Available online: 28/06/2016

\section{Key words:}

Brown algae; Sargassum

vulgare; cytotoxic activity;

Jurkat; trypan blue exclusion

assay.

\begin{abstract}
The discovery of cancer drugs that effectively destroy cancer cells or stop their growth without toxicity to normal cells is a challenge to enhance the therapeutic effects and reduce side effects. Many papers have highlighted the implication of marine algae that show anticancer activity. In this report, we assessed the cytotoxic activity of two different crude extracts from Sargassum vulgare (Sargassaceae), a marine brown algae collected from the Lebanese coast, against Jurkat human cancer cell line using trypan blue exclusion test. Both extracts, water: ethanol extract and chloroform: ethanol extract, showed cytotoxic activity against Jurkat cancer cell line with IC50 values of $136.907 \mu \mathrm{g} / \mathrm{mL}$ and $49.056 \mu \mathrm{g} / \mathrm{mL}$, respectively after 72 hours of treatment. Further research designed to isolate and identify novel and efficient anticancer drug candidates from these seaweed extracts need to be explored.
\end{abstract}

\section{INTRODUCTION}

Cancer is a leading cause of death worldwide. Leukemia, also called blood cancer, is a part of malignancies usually characterized by abnormal and excessive proliferation of precursors of the white blood cells, blocked at a stage of differentiation (Pui et al., 2008). In this case, the bone marrow produces white blood cells more than the body needs. These cells, in turn, begin to invade the healthy blood cells, resulting thereafter anemia, bleeding, and infections. Leukemia remains a serious public health problem with an estimated mortality rate of death 24,450 and an estimated incidence rate of 54,270 new

\section{* Corresponding Author}

Prof. dr. Mona Diab-Assef, Molecular and cellular biochemistry of cancer Laboratory, Doctoral School of Science and Technology, Lebanese University, Hadath, Lebanon. E-mail: mdiabassaf@ul.edu.lb, Tel /fax : 009611681552 cases of leukemia in 2015 (Siegel et al., 2015). Most of the anticancer drugs currently used in chemotherapy are cytotoxic to normal cells and which might cause several undesirable side effects (Prucker et al., 2009). The discovery of new anticancer drug with less side effects and toxicity has become a need for many researchers. In this context, natural products derived from plants, marine organism and micro-organism have interested many scientists (Cragg and Newman, 2005). Over the past years, nature has played an important role as a source of new drugs. The marine ecosystem appears today as a substantial source of new natural molecules with unique biological activity and original chemical structure, which can be useful while looking for effective drugs for the treatment of human diseases (Haefner, 2003). Among these marine organisms, marine algae (also called seaweed) have been one of the natural sources of bioactive compounds (Smit, 2004). Seaweed is classified into three broad groups based on pigmentation- brown, red and green seaweed. 
They are ubiquitous in our daily lives, and their uses are many and varied. Besides food uses, they take an important place in agriculture (fertilizers), in the pharmaceutical industry (coating of medications) and in the field of cosmetics (soap, cream, toothpaste), and products cleaning, etc. (Person, 2011). The algae consist of proteins, a small amount of lipids compared to the high percentage of carbohydrates that are in the form of polysaccharides such as alginates, carrageenan and ulvans. They also contain high contents of minerals and vitamins. In addition, they synthesize and accumulate small amounts of secondary metabolites which have promising pharmacological and biological activities. Recent findings showed that seaweeds had anticancer, antibacterial, antioxidant, and many other effects (El Gamal, 2010; Smit, 2004). Sargassum is a genus of brown algae of Phaeophyceae class, Fucales order, and Sargassaceae family, and which contains about 400 different species identified so far (Mattio and Payri, 2011). This type of algae is consumed as food and medicine in many cultures. The treatment of thyroid diseases such as goiter is one of the important traditional uses to Sargassum (Liu et al., 2012). The iodine presence in such algae appears to play an important role in the therapy. A wide range of pharmacological properties of crude extracts or isolated components of Sargassum such as phlorotannin, fucoidan, sterol and glycolipid, was discovered. It's about anticancer, antibacterial, antifungal, antiviral, antiinflammatory, antioxidant, hypoglycemic, and hypolipidemic activities, etc. (Mattio and Payri, 2011). Much work has been devoted to assessing the anticancer activity of the crude extracts or isolated compounds of the brown algae of the genus Sargassum. De Sousa et al. (2007) provide that alginate-type polysaccharide extracts of Sargassum vulgare inhibit in vivo the rate of proliferation of sarcoma 180 cells transplanted in mice, as observed by the reduction of the expression of Ki67 (De Sousa et al., 2007). Also, another type of polysaccharide heterofucan (1.5 $\mathrm{mg} / \mathrm{mL}$ ) isolated from $S$. filipendula shows a decrease in cell proliferation of HeLa (cervical cancer) (Silva Costa et al., 2011). Similarly, De la Mare et al. (2012) isolate a plastoquinone from $S$. heterophyllum with anti-proliferative action against MDA-MB231 (human breast carcinoma) after 96 hours, at an inhibitory concentration IC50 of $67.4 \pm 5.9 \mu \mathrm{M}$ (De la Mare et al., 2012). However, Khanavi et al. (2010) show the cytotoxicity of the hexane fraction and of the methanolic extract total S. swartzii against the proliferation of cancer cells of Caco-2 (colon adenocarcinoma) at an IC 50 of $99.9 \pm 19.38 \mu \mathrm{g} / \mathrm{mL}$, and T47D (breast carcinoma) at an IC 50 of $205.21 \pm 84.1 \mu \mathrm{g} / \mathrm{mL}$, respectively (Khanavi et al., 2010). On the other hand, Namvar et al. (2013) exhibit the inhibition of the growth of both tumor cells, MCF-7 and MDA-MB-231, in a dose and time-dependent manner, after being treated for $24 \mathrm{~h}$ with the methanol extract of $S$. muticum at an IC 50 of $22 \mu \mathrm{g} / \mathrm{mL}$ and $55 \mu \mathrm{g} / \mathrm{mL}$, respectively ( Namvar et al., 2013). Crude extracts and various compounds such as sulfated polysaccharide of $S$. filipendula (Silva Costa et al., 2011), the sargaquinoic acid of $S$. heterophyllum (De la Mare et al., 2012), a kind of chromene derived from S. siliquastrum (Heo et al., 2011), the hexane fraction of S. swartzii (Khanavi et al.,
2010), and the methanol extract of S. muticum (Namvar et al., 2013) showed a pro-apoptotic action of the HeLa, MDA-MB-231, HL-60, Caco-2 and MCF-7 cells respectively. By decreasing the size and number of vessels, the methanolic extract of Sargassum muticum (50 and $100 \mu \mathrm{g} / \mathrm{mL}$ ) implanted in vivo into fertilized eggs, was able to induce an anti-angiogenic activity in the chorioallantoic membrane (Namvar et al., 2013). The work presented above is not an exhaustive list. Sargassum vulgare, a marine brown algae, was found abundantly at the Lebanese coast. This study aims at assessing the cytotoxic activity of ethanol: water extracts (50: 50, V/V) and ethanol: chloroform extracts (50: $50, \mathrm{~V} / \mathrm{V})$ prepared from Sargassum vulgare against the human cancer cell line Jurkat (acute lymphoblastic leukemia) using trypan blue exclusion method. Since no researcher in Lebanon and abroad examined the cytotoxic activity of the crude extracts or the bioactive compounds derived from Sargassum vulgare, a brown seaweed species collected on the Lebanese coast against human leukemia cell lines, we decided to select the Jurkat cell line for this study.

\section{MATERIAL AND METHODS}

\section{Chemicals}

Chemicals and reagents used to study anti-proliferative activities were purchased from Sigma-Aldrich Co. (Beirut, Lebanon) while the other chemicals, solvents, and reagents were purchased from Alpha Co. (Beirut, Lebanon). The fetal bovine serum was the only chemical obtained from CELBIO (Milano, Italy).

\section{Plant materials}

Algae were manually collected from El Barbara beach in Lebanon at the end of May 2015. The collected samples were transported to the laboratory where they were first washed thoroughly with fresh water to remove slats, sand, and epiphytes, then with hydrochloric acid $10 \%$ for a few seconds to remove the organic matter, and finally with distilled water. Then, the algae were frozen at $-80^{\circ} \mathrm{C}$ and lyophilized. After drying, the algae were ground to powder in a blender. Voucher specimen No 700 was botanically authenticated by Dr Mona Tannoury, Biology Department, Faculty of Sciences II, Lebanese University and deposited in the Biology Department Herbarium, Faculty of Sciences II, Lebanese University.

\section{Sample extraction}

The dried and ground sample (2 gms) of Sargassum vulgare was dissolved in $40 \mathrm{~mL}$ of ethanol: water ( $\mathrm{v}: \mathrm{v})$ by maceration during $24 \mathrm{hrs}$. The material was filtered by using Whatman paper No 1, whereas the extract plant was transferred to $50 \mathrm{ml}$-round-bottom flask, and then taken with rotary vacuum evaporator. Moreover, these crude extracts were freeze-dried by lyophilization. While another dried and ground sample (2 gms) of $S$. vulgare was extracted with chloroform: ethanol by maceration similar to the extraction of ethanol: water protocol (Choi et al., 2004). 


\section{Cell lines and culture condition}

Jurkat cells ( $\mathrm{T}$ lymphocyte cells): The cells are suspended lymphoblasts. The growth medium was Advanced RPMI 1640 (Gibco/Invitrogen), 10\% fetal bovine serum (Hyclone), $10 \mathrm{mM}$ Hepes $100 \mathrm{U} / \mathrm{mL}$ penicillin, and $100 \mu \mathrm{g} / \mathrm{mL}$ streptomycin, $5 \% \mathrm{CO}_{2}\left(37^{\circ} \mathrm{C}\right)$. Liquid Nitrogen Storage: Complete growth medium supplemented with $5 \%(\mathrm{v} / \mathrm{v})$ DMSO in $1 \mathrm{~mL}$ aliquots of approximately $5 \times 10^{6}$ cells. RPMI 1640 medium for suspension cells with fetal bovine serum (FBS) (Saab et al., 2011; Lampronti et al., 2006).

\section{Cell viability assay}

Jurkat cells $(20,000$ cells/ dish) were seeded in 24-well plates. Two wells were prepared for each concentration. The cells treated with $S$. vulgare at different concentrations were compared with untreated controls. Besides, Jurkat cells were treated with ethanol: water $S$. vulgare extract at different concentrations as well as chloroform: ethanol $S$. vulgare extract. The plates were incubated for 3 days. The cytotoxicity was determined by trypan blue staining. The cell suspension $(20 \mu \mathrm{L})$ was taken from the well and mixed with $20 \mu \mathrm{L}$ trypan blue. The living cells weren't stained and can be easily distinguished from the blue dead cells which absorbed the dye because of their damaged membrane. After 24, 48 and $72 \mathrm{~h}$ of incubation, $10 \mu \mathrm{L}$ of cell suspension and an equal volume of trypan blue were mixed. Then, the mixture was loaded on a Neubauer hemocytometer and examined under a microscope to count the viable cells (clear, not blue) (Zandi et al., 2010).

\section{Statistical analysis}

All experiments were carried out in triplicate. The data were expressed as means \pm SD and the differences were evaluated by one-way analysis of variance (ANOVA) test completed by Dunnett's test. The differences were considered significant at $* * p$ $<0.01$. The $50 \%$ inhibitory concentration $\left(\mathrm{IC}_{50}\right)$ was calculated by nonlinear regression curve with the use of Prism Graphpad Prism version 4.0 for Windows [GraphPad Software, San Diego, CA, USA].

\section{RESULTS AND DISCUSSION}

Different solvents were chosen to prepare extracts of algae and used as a mixture - water which is the most common polar solvent, ethanol which is known as an extraction solvent for polar compounds, and chloroform which is a non-polar solvent for the extraction of non-polar compounds. The crude extraction of dried brown seaweed Sargassum vulgare prepared by two different solvent mixtures was used to calculate the yield of each extract expressed as a percentage for $15 \mathrm{~g}$ of dry and ground plant material. The highest yield is marked for the water: ethanol extract with a value of $20.039 \% \mathrm{w} / \mathrm{w}$ while the low yield of $3.533 \% \mathrm{w} / \mathrm{w}$ is recorded for the ethanol: chloroform extract. In order to evaluate the Lebanese ethanol: chloroform S. vulgare extract and ethanol: water $S$. vulgare extract, Jurkat human cancer cells were seeded at initial cell concentration 20,000 cells $/ \mathrm{mL}$ and then cultured for 3 days either in the presence or absence of $S$. vulgare extracts at concentrations ranging from $25-1000 \mu \mathrm{g} / \mathrm{mL}$. The trypan blue exclusion assay showed that with an increase in concentrations of algal extract and in the duration of treatment (24, 48 and 72 hours), Jurkat cell viability was significantly decreased according to the negative control free extract. This infers the existence of time and dose dependent properties of Sargassum vulgare extracts against Jurkat tumor cell lines. Consequently, the ethanol: chloroform extract and ethanol: water extract prepared from S. vulgare were able to exert anti-proliferative activities against Jurkat human cancer cells with IC50 values $49.056 \pm 3.2 \mu \mathrm{g} / \mathrm{mL}$ and $136.907 \pm 5.2$ $\mu \mathrm{g} / \mathrm{mL}$, respectively after 72 hours of treatment (Figs.1 \& 2). The result shows that the chloroform: ethanol extracts have better IC 50 values compared to the ethanol: water extracts.

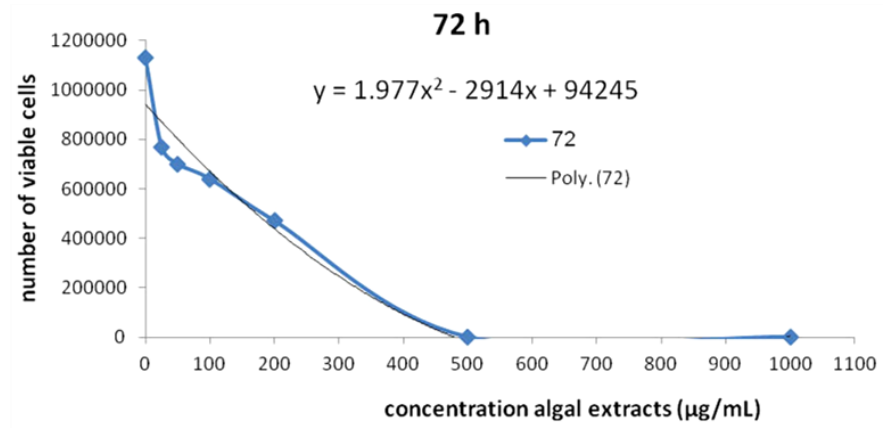

Fig. 1: treatment with ethanol: water extract $(\mathrm{V}: \mathrm{V})$ after 72 hours of treatment.

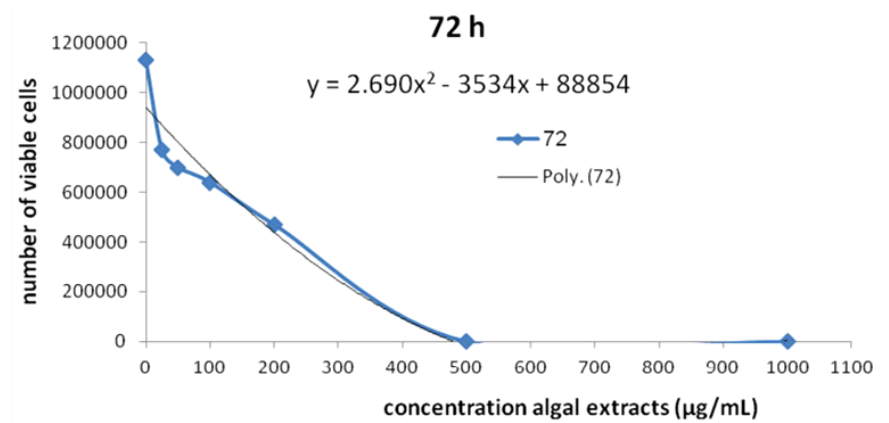

Fig. 2: treatment with ethanol: chloroform extract $(\mathrm{V}: \mathrm{V})$ after 72 hours of treatment.

Therefore, the ethanol: chloroform extracts of S. vulgare are more cytotoxic than the ethanol: water extracts. Hence, this result emphasizes the influence of the choice of solvent extraction on the cytotoxic activity of seaweed extracts against cancer cell lines.Some literature highlight the potential implications of marine algae which exhibit antitumor activity (Guedes et al., 2013). Our preliminary results show the cytotoxic activity of the crude extracts of the marine brown algae Sargassum vulgare collected from the Lebanese coast against Jurkat cancer cell line using trypan blue exclusion assay. The cell viability was decreased in a time and dose dependent manner. Similar results were also observed by Zubia et al. (2009) who emphasize a strong cytotoxicity of the crude extracts on Jurkat cancer cell line (Zubia et al., 2009). Jurkat cell viability decreased significantly after a treatment of $24 \mathrm{~h}$ with extracts prepared from marine red algae 
Asparagopsis armata, Brongniartella byssoides, Heterosiphonia plumose, and Calliblepharis jubata. Similarly, the results obtained by Guedes et al. (2013) show that the aqueous extract of Sargassum vulgare was significantly cytotoxic against Hep-2 with IC50 of $18.7 \pm 3.8 \mu \mathrm{g} / \mathrm{mL}$ (Guedes et al., 2013). Many other studies have evaluated the cytotoxic effect of various algae species of the genus Sargassum as Sargassum swartzii and Sargassum sp. which showed similar results in terms of their cytotoxic effects. The fraction of hexane and the total methanol extract of $S$. swartzii exhibit cytotoxic activity against Caco- 2 with IC50 of $99.9 \pm 19.38$ $\mu \mathrm{g} / \mathrm{mL}$, and T47D with IC50 of $205.21 \pm 84.1 \mu \mathrm{g} / \mathrm{mL}$, respectively (Khanavi et al., 2010). Moreover, Mary et al. (2012) reported that the treatment with a concentration range of 100 to $300 \mu \mathrm{g} / \mathrm{mL}$ of ethanol extract of Sargassum sp. reduces the cell viability of both Hep-2 and MCF-7 cell lines in a dose dependent manner with an IC 50 value of $200 \mu \mathrm{g} / \mathrm{mL}$ and $250 \mu \mathrm{g} / \mathrm{mL}$, respectively (Mary et al., 2012). In addition, various types of lipids, steroids and sterols isolated from $S$. carpophyllum also have cytotoxic activity against various cancer cell lines, including HL-60 (human promyelocytic leukemia), P388 (murine leukemia), MCF-7 (breast cancer), HCT8 (colon cancer), 1A9 (carcinoma human ovary), HOS (human osteosarcoma), and PC-3 (prostate adenocarcinoma) (Tang et al., 2002). Likewise, some plastoquinones isolated from the methanol extract of $S$. micracanthum exhibit cytotoxic activity against cancer cell line of colon adenocarcinoma 26-L5 (high cytotoxicity with IC50 of 1.51 and $1.69 \mu \mathrm{g} / \mathrm{mL}$, and moderate activity with IC50 of $17.5 \mu \mathrm{g} / \mathrm{mL}$ ) (Mori et al., 2005). An MTT test shows that the polysaccharide fractions from $S$. pallidum $(1 \mathrm{mg} / \mathrm{mL})$ have a high antitumor activity against cancer cells HepG2 (hepatocellular human liver carcinoma), A549 (human lung carcinoma), and GC803 (stomach cancer) (Ye et al., 2008). On the other hand, the MTT test and the trypan blue exclusion assay show a decrease in viable cells following exposure lines K562 and Daudi to the extract by cold distilled water of $S$. oligocystum at a concentration of 400 and $500 \mu \mathrm{g} / \mathrm{mL}$ (Zandi et al., 2010). The methanolic extract prepared from Sargassum muticum inhibits the growth of both cell lines MCF-7 and MDA-MB-231 in a dose and time-dependent manner, with IC50 values of $22 \mu \mathrm{g} / \mathrm{mL}$ and $55 \mu \mathrm{g} / \mathrm{mL}$, respectively, after a 24 hour treatment ( Namvar et al., 2013). While the methanolic extract of Sargassum ilicifolium inhibits the proliferation of five lines of human cancer cells- MCF-7, HeLa, MDA-MB-231, HepG2, and HT-29- in a time and dose dependent manner after $24 \mathrm{~h}$ treatment, for IC50 values 37, 60, 62, 120, 300 $\mu \mathrm{g} / \mathrm{mL}$, respectively (Namvar et al., 2014).

\section{CONCLUSION}

Our study indicates that the brown marine algae Sargassum vulgare collected from the Lebanese coast have promising anticancer activity. Depending on the extraction solvent used, the ethanol: chloroform extract gave the best result, i.e. high cytotoxic activity against Jurkat human leukemic cell line. This result highlights how the marine algae collected from the Lebanese coast can be an important source to discover new effective antitumor compounds. Further research is needed to isolate and identify the bioactive compound of Sargassum vulgare collected on the Lebanese coast, and also to elucidate the mechanism procedure by which the compound produces the cytotoxic effect the compound's effect on the cell cycle and their ability to induce apoptosis.

\section{REFERENCES}

Choi H-K, Choi YH, Verberne M, Lefeber AWM, Erkelens C, Verpoorte R. Metabolic fingerprinting of wild type and transgenic tobacco plants by $1 \mathrm{H}$ NMR and multivariate analysis technique. Phytochemistry, 2004; 65(7):857-864.

Cragg GM, Newman DJ. Plants as a source of anti-cancer agents. Journal of Ethnopharmacology, 2005; 100(1-2):72-79.

De la Mare J, Lawson JC, Chiwakata MT, Beukes DR, Edkins $\mathrm{AL}$, Blatch GL. Quinones and halogenated monoterpenes of algal origin show anti-proliferative effects against breast cancer cells in vitro. Investigational New Drugs, 2012; 30(6):2187-2200.

De Sousa APA, Torres MR, Pessoa C, Moraes MO de, Filho FDR, Alves APNN, et al. In vivo growth-inhibition of Sarcoma 180 tumor by alginates from brown seaweed Sargassum vulgare. Carbohydrate Polymers, 2007; 69(1):7-13.

El Gamal AA. Biological importance of marine algae. Saudi Pharmaceutical Journal, 2010; 18(1):1-25.

Esseily F, El Ezzy M, Gali-Muhtassib H, Safi S, Esseily J, DiaAssaf M, Lampronti I \& Saab A. The ethanol fraction from the stem of Berberis libanotica inhibits the viability of adult T cell leukemia. Minerva Biotecnologica, 2012; 24(4).

Guedes ÉAC, Silva TG da, Aguiar JS, Barros LD de, Pinotti LM, Sant'Ana AEG. Cytotoxic activity of marine algae against cancerous cells. Revista Brasileira de Farmacognosia, 2013; 23(4):668-673.

Haefner B. Drugs from the deep: marine natural products as drug candidates. Drug Discovery Today, 2003; 8(12):536-544.

Heo S-J, Kim K-N, Yoon W-J, Oh C, Choi Y-U, Affan A, et al. Chromene induces apoptosis via caspase- 3 activation in human leukemia HL-60 cells. Food and Chemical Toxicology, 2011; 49(9):1998-2004.

Khanavi M, Nabavi M, Sadati N, Shams Ardekani M, Sohrabipour J, Nabavi SMB, et al. Cytotoxic activity of some marine brown algae against cancer cell lines. Biol Res, 2010; 43(1):31-37.

Lampronti I, Saab AM, Gambari R. Antiproliferative activity of essential oils derived from plants belonging to the Magnoliophyta division. Int J Oncol, 2006; 29(4):989-995.

Liu L, Heinrich M, Myers S, Dworjanyn SA. Towards a better understanding of medicinal uses of the brown seaweed Sargassum in Traditional Chinese Medicine: A phytochemical and pharmacological review. Journal of Ethnopharmacology, 2012; 142(3):591-619.

Mary JS, Vinotha P, Pradeep AM. Screening for in vitro cytotoxic activity of seaweed, Sargassum $s p$. against Hep-2 and MCF-7 cancer cell lines. Asian Pac J Cancer Prev, 2012; 13(12):6073-6076.

Mattio L, Payri CE. 190 Years of Sargassum Taxonomy, Facing the Advent of DNA Phylogenies. The Botanical Review, 2011; 77(1):3170 .

Mori J, Iwashima M, Wakasugi $\mathrm{H}$, Saito $\mathrm{H}$, Matsunaga $\mathrm{T}$, Ogasawara M, et al. New Plastoquinones Isolated from the Brown Alga, Sargassum micracanthum. Chemical and Pharmaceutical Bulletin, 2005; 53(9):1159-1163.

Namvar F, Baharara J, Mahdi AA. Antioxidant and Anticancer Activities of Selected Persian Gulf Algae. Indian J Clin Biochem, 2014; 29(1):13-20.

Namvar F, Mohamad R, Baharara J, Zafar-Balanejad S, Fargahi F, Rahman HS. Antioxidant, Antiproliferative, and Antiangiogenesis Effects of Polyphenol-Rich Seaweed (Sargassum muticum). BioMed Research International, 2013; 2013:e604787.

Person J. Algues, filières du futur: Livre Turquoise. Editions Adebiotech; 2011. 163 p. 
Prucker C, Attarbaschi A, Peters C, Dworzak MN, Pötschger U, Urban $\mathrm{C}$, et al. Induction death and treatment-related mortality in first remission of children with acute lymphoblastic leukemia: a population-based analysis of the Austrian Berlin-FrankfurtMünster study group. Leukemia, 2009; 23(7):1264-1269.

Pui C-H, Robison LL, Look AT. Acute lymphoblastic leukaemia. Lancet, 2008; 371(9617):1030-1043.

Siegel RL, Miller KD, Jemal A. Cancer statistics, 2015. CA: A Cancer Journal for Clinicians, 2015; 65(1):5-29.

Saab AM, Lampronti I, Grandini A, Borgatti M, Sacchetti G, Gambari R \& Guerrini A. Antiproliferative and Erythroid Differentiation Activities of Cedrus libani Seed Extracts against K562 Human Chronic Myelogenus Leukemia Cells. International Journal of Pharmaceutical \&amp; Biological Archives, 2011; 2(6):1744-1748.

Silva Costa L, Silva Telles CB, Medeiros Oliveira R, Duarte Barreto Nobre LT, Dantas-Santos N, Barros Gomes Camara R, et al. Heterofucan from Sargassum filipendula Induces Apoptosis in HeLa Cells. Marine Drugs, 2011; 9(4):603-614.

Smit AJ. Medicinal and pharmaceutical uses of seaweed natural products: A review. Journal of Applied Phycology, 2004; 16(4):245-262.

Tang H-F, Yi Y-H, Yao X-S, Xu Q-Z, Zhang S-Y, Lin H-W. Bioactive steroids from the brown Alga Sargassum carpophyllum. Journal of Asian Natural Products Research, 2002; 4(2):95-101.
Ye H, Wang K, Zhou C, Liu J, Zeng X. Purification, antitumor and antioxidant activities in vitro of polysaccharides from the brown seaweed Sargassum pallidum. Food Chemistry, 2008; 111(2):428-432.

Zandi K, Ahmadzadeh S, Tajbakhsh S, Rastian Z, Yousefi F, Farshadpour F, et al. Anticancer activity of Sargassum oligocystum water extract against human cancer cell lines. Eur Rev Med Pharmacol Sci, 2010; 14(8):669-673.

Zubia M, Fabre M-S, Kerjean V, Deslandes E. Antioxidant and cytotoxic activities of some red algae (Rhodophyta) from Brittany coasts (France). Botanica Marina, 2009; 52(3):268-277.

\section{How to cite this article:}

Tannoury MY, Elia JM, Saab AM, Makhlouf HY, Abboud JS, Daou-Chabo RJ, Diab-Assaf M. Evaluation of Cytotoxic Activity of Sargassum vulgare From the Lebanese Coast Against Jurkat Cancer Cell Line. J App Pharm Sci, 2016; 6 (06): 108-112. 